\title{
Intermédialités
}

Histoire et théorie des arts, des lettres et des techniques

Intermediality

History and Theory of the Arts, Literature and Technologies

\section{Intermediality, Intertextuality, and Remediation: A Literary Perspective on Intermediality}

\section{Irina O. Rajewsky}

Numéro 6, automne 2005

Remédier

Remediation

URI : https://id.erudit.org/iderudit/1005505ar

DOI : https://doi.org/10.7202/1005505ar

Aller au sommaire du numéro

Éditeur(s)

Centre de recherche sur l'intermédialité

ISSN

1705-8546 (imprimé)

1920-3136 (numérique)

Découvrir la revue

Citer cet article

Rajewsky, I. O. (2005). Intermediality, Intertextuality, and Remediation: A

Literary Perspective on Intermediality. Intermédialités / Intermediality, (6),

43-64. https://doi.org/10.7202/1005505ar
Résumé de l'article

Le concept d'intermédialité fait aujourd'hui pleinement partie des débats théoriques portant sur la littérature et les autres arts et médias. En adoptant une définition générale de l’intermédialité, il est aisé de faire converger les opinions. Par contre, le spectre des recherches s'élargit considérablement, de façon contradictoire, même, dès qu'il s'agit de différencier davantage, de rendre plus claire telle ou telle vision particulière de l'intermédialité et de définir (selon les besoins) la notion d'intermédialité dans un sens plus strict. Partant d'un bilan des débats théoriques actuels, cet article propose d'élucider et de préciser une approche particulière de l'intermédialité, en introduisant trois sous-catégories plus restreintes du concept : " transposition médiatique ", " combinaison médiatique » et " référence intermédiale ». En comparant ces sous-concepts avec celui de " remédiation », developpé par Bolter et Grusin, on se demandera sur quels types d'objets et d'objectifs de recherche cette conception de l'intermédialité gagne une valeur heuristique et pratique. Ceci se vérifiera tout particulièrement lorsqu'il s'agit d'analyser de façon détaillée des configurations médiatiques concrètes et leurs stratégies de production de sens. 


\title{
Intermediality, Intertextuality, and Remediation: A Literary Perspective on Intermediality
}

\author{
IRINA O. RAJEWSKY
}

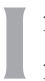

ntermedial research-at least in the German academic context-has by now outgrown its infancy. The initial development of intermedial research perspectives has been followed by reappraisals, and the term "intermediality" itself is no longer regarded as that ubiquitous catchword which came onto the scene in the 1990s with such striking success. ${ }^{1}$ Nevertheless, there appears to be sustained interest in the investigation of intermedial configurations and in intermedial research perspectives in general. This is reflected not least by the large, and presently still increasing, number of multidisciplinary publications and conferences devoted to the topic, and by the ongoing clarification and differentiation of the research perspectives themselves. It is also demonstrated by the growing international recognition of the concept of intermediality that initially had come to be part of a fixed critical inventory mainly in the German-speaking research community ${ }^{2}$ : calls for a conceptual and terminological turn towards intermediality increasingly show up in English-language articles, especially in the area traditionally called interart(s) studies, a field in which the concept of intermediality has for a long time been largely neglected. ${ }^{3}$

1. The concept of intermediality, as it is used here, is to be distinguished from the American term "intermedia". Cf. notes 16 and 18, below.

2. Besides Germany, Canada in particular, and above all the Université de Montréal, established itself with the launch of the CRI (Centre de recherche sur l'intermédialité) in 1997 as a "stronghold" of research on intermediality.

3. Cf. Ulrich Weisstein, "Literature and the (Visual) Arts. Intertextuality and Mutual Illumination," in Ingeborg Hoesterey and Ulrich Weisstein (eds.), Intertextuality: German Literature and Visual Art from Renaissance to the Twentieth Century, Columbia, South Carolina, Camden House, 1993, p. 3; Claus Clüver, "Inter textus / Inter artes / Inter media," in Komparatistik. Jahrbuch der Deutschen Gesellschaft für Allgemeine und Vergleichende Literaturwissenschaft (2000/2001), Heidelberg, Synchron, 2001, p. 14, p. 43. 
Taking into account the long tradition of interarts studies, it becomes apparent that much of what is generally treated under the heading of intermediality is in no way a novelty. While it is true that some new aspects and problems have emerged, especially with respect to electronic and digital media, intermedial relations and processes per se remain phenomena which have been recognized for a long time. This fact is easily overlooked on account of those approaches to intermediality that concentrate specifically on so-called New Media; traditional interarts studies, however, have in their own way consistently acknowledged it. The sustained success and growing international recognition of the concept of intermediality, therefore, point less to new types of problems per se than (at least potentially) to new ways of solving problems, new possibilities for presenting and thinking about them, and to new, or at least to different views on medial border-crossings and hybridization; in particular, they point to a heightened awareness of the materiality and mediality of artistic practices and of cultural practices in general. Finally, the concept of intermediality is more widely applicable than previously used concepts, opening up possibilities for relating the most varied of disciplines and for developing general, transmedially relevant theories of intermediality.

Certainly what is at issue here is not one unifying theory of intermediality or one intermedial perspective as such. From its beginnings, "intermediality" has served as an umbrella-term. A variety of critical approaches make use of the concept, the specific object of these approaches is each time defined differently, and each time intermediality is associated with different attributes and delimitations. The specific objectives pursued by different disciplines (e.g. media studies, literary studies, sociology, film studies, art history) in conducting intermedial research vary considerably. In addition, a host of related terms has surfaced in the discourse about intermediality which are themselves defined and used in a variety of ways (e.g. multimediality, plurimediality, crossmediality, infra-mediality, media-convergence, media-integration, media-fusion, hybridization, and so forth). More recently, researchers have begun to formally specify their particular conception of intermediality through such epithets as transformational, discursive, synthetic, formal, transmedial, ontological, or genealogical intermediality, primary and secondary intermediality, or so-called intermedial figuration. ${ }^{4}$

4. On "transformational intermediality, cf. Yvonne Spielmann, Intermedialität. Das System Peter Greenaway, München, Fink, 1998 and Yvonne Spielmann, "Intermedia and the Organization of the Image: Some Reflections on Film, Electronic, and Digital Media," Iris, No. 25, spring 1998, p. 61-74; on "discursive intermediality," cf. Irene Albers, Sehen und Wissen. Das Photographische im Romanwerk Émile Zolas, München, 
The current state of affairs, then, is a proliferation of heterogeneous conceptions of intermediality and heterogeneous ways in which the term is used. This proliferation may be rewarding, but it is also confusing, leading not infrequently to vagueness and misunderstandings. Hence it becomes necessary to define one's own particular understanding of intermediality more precisely, and to situate one's individual approach within a broader spectrum-an objective that current scholarship for the most part has not sufficiently realized, thereby impeding potentially fruitful intradisciplinary and interdisciplinary discussions.

Taking all of this into account, it is obvious that difficulties arise when any one individual approach to intermediality lays claim to having grasped "the intermedial" as such. It would seem preferable to restrict the validity of one's own conclusions by clarifying the aims and the object of one's particular conception of intermediality, thereby distinguishing one's own approach from those of others. This, then, is the objective of the present essay: to specify and to position my own particular conception of intermediality, a conception based in (though not limited to) literary studies and introduced in my earlier publications. 5 The essay aims to identify the distinct heuristic and practical value of such a conception,

Fink, 2002, p. 27 et sq.; on "synthetic," "formal," "transmedial," and "ontological intermediality," cf. Jens Schröter, "Intermedialität. Facetten und Probleme eines aktuellen medienwissenschaftlichen Begriffs," in Montage/AV, Vol. 7, No. 2, 1998, p. 129-154; on "genealogical intermediality," cf. André Gaudreault, Philippe Marion, "The Cinema as a Model for the Genealogy of Media," in Convergence, Vol. 8, No. 4, 2002, p. 12-18; on "primary" and "secondary intermediality," cf. Rainer Leschke, Einführung in die Medientheorie, München, Fink, 2003; on "intermedial figuration," cf. Joachim Paech, "Intermediale Figuration-am Beispiel von Jean-Luc Godards Histoire(s) du Cinéma," in Jutta Eming, Annette Jael Lehmann, Irmgard Maassen (eds.), Mediale Performanzen. Historische Konzepte und Perspektiven, Freiburg, Rombach, 2002, p. 275-295.

5. Cf. Irina O. Rajewsky, Intermedialität, Tübingen, Basel, Francke, 2002; Intermediales Erzählen in der italienischen Literatur der Postmoderne: Von den giovani scrittori der 80er zum pulp der 90er Jahre, Tübingen, Narr, 2003; "Intermedialität 'light'? Intermediale Bezüge und die 'bloße' Thematisierung des Altermedialen," in Roger Lüdeke, Erika Greber (eds.), Intermedium Literatur. Beiträge zu einer Medientheorie der Literaturwissenschaft, Göttingen, Wallstein, 2004, p. 27-77. It is as a reference to literary studies, rather than to literary works, that the title of my essay is to be understood. By "A Literary Perspective...," I mean less a perspective coming from literature in the narrow sense, and more a perspective on intermediality informed by literary studies, and specifically by its conceptual and heuristic objectives and approaches. Accordingly, my remarks on intermediality will not confine themselves to discussing literary texts; instead, I will be taking various forms of medial articulation into account. 
a value that will be contextualized within the larger field of the various existing approaches to intermediality and of their varying objectives.

\section{INTERMEDIALITY IN A BROAD SENSE - INTERMEDIALITY IN A NARROW SENSE}

Trying to reduce to a common denominator the host of current conceptions of intermediality and the vast range of subject-matter they cover, we are forced to appeal to a very broadly conceived concept which would be limited neither to specific phenomena or media, nor to specific research objectives. In this sense, intermediality may serve foremost as a generic term for all those phenomena that (as indicated by the prefix inter) in some way take place between media. "Intermedial" therefore designates those configurations which have to do with a crossing of borders between media, and which thereby can be differentiated from intramedial phenomena as well as from transmedial phenomena (i.e., the appearance of a certain motif, aesthetic, or discourse across a variety of different media). ${ }^{6}$

A broad intermediality concept of this kind allows for making fundamental distinctions between intra-, inter- and (ultimately) transmedial phenomena, at the same time representing a transmedially useful category. Yet such a broad concept does not permit us to derive a single theory that would uniformly apply to the entire, heterogeneous subject-matter covered by all the different conceptions of intermediality, nor does it help us to characterize more precisely any one individual phenomenon on its own distinct formal terms. Accordingly, in order to cover and to uniformly theorize specific intermedial manifestations, more narrowly conceived (and often mutually contradictory) conceptions of intermediality have been introduced, each of them with its own explicit or implicit premises, methods, interests, and terminologies.

Multiple factors contribute to the heterogeneity of these more narrow conceptions. Yet an assessment of the current intermediality debate leads to the identification of three fundamental distinctions that underlie different conceptions of intermediality: the first is between synchronically and diachronically conceived approaches. In fact, studies of intermediality include both the "synchronic

6. An example for this is the aesthetic of futurism, which was realized in different media (text, painting, sculpture, etc.) with the formal means specific to each medium. The concrete realization of this aesthetic is in each case necessarily media-specific, but per se it is nevertheless not bound to a specific medium. Rather, it is transmedially available and realizable, i.e., available and realizable across media borders. In a similar way, one can speak of a transmedial narratology, referring to those narratological approaches that may be applied to different media, rather than to a single medium only. 
research perspective, which develops a typology of specific forms of intermediality, and the diachronic perspective of an intermedial history of media." 7 The diachronic perspective is for instance taken up by media historians whose work focuses on the intersections of different media with one another. Other kinds of diachronic studies (often combined with a synchronic orientation) analyze the historical changes in the form and function of intermedial practices in given media products, ${ }^{8}$ and still others address so-called genealogical intermediality. The latter approaches investigate the relations between different media, for instance in a context where a particular medium assumes a newly found dominance, when a new medium emerges or "is born." According to André Gaudreault and Philippe Marion, in any such "birth," certain intermedial qualities necessarily and always come to the fore. ${ }^{9}$ Thus, a second fundamental possibility for distinguishing between various conceptions of intermediality emerges, operating on a level entirely different from the first.

Broadly speaking, the current debate reveals two basic understandings of intermediality, which are not in themselves homogeneous. The first concentrates on intermediality as a fundamental condition or category while the second approaches intermediality as a critical category for the concrete analysis of specific individual media products or configurations - a category that of course is useful only in so far as those configurations manifest some form of intermedial strategy, constitutional element or condition. The distinction between these two basic categories - these two poles structuring the intermediality debate-inevitably recalls the discussion about intertextuality that occurred from the 1970 s through the 1990s, all the more since intertextuality in its various narrow or broad conceptions has been a starting point for many attempts to theorize the

7. Jürgen E. Müller, "Mediengeschichte intermedial: Perspektiven, Postulate, Prognosen," in Frank Furtwängler et al. (eds.), Zwischen-Bilanz. Eine Festschrift zum 60. Geburtstag von Joachim Paech, www.uni-konstanz.de/paechzoO2, 2002.

8. Cf., for example, Werner Wolf, The Musicalization of Fiction. A Study in the Theory and History of Intermediality, Amsterdam, Atlanta, Rodopi, 1999; Christian v. Tschilschke, Roman und Film. Filmisches Schreiben im französischen Roman der Postavantgarde, Tübingen, Narr, 2000; Irina O. Rajewsky, Intermediales Erzählen in der italienischen Literatur der Postmoderne.

9. Gaudreault and Marion develop a theory of the "double birth" of every (new) medium, which presumes in the first stage of birth an "initial intermediality" and in the second a "subjugated" or "negotiated intermediality." (André Gaudreault, Philippe Marion, "The Cinema as a Model for the Genealogy of Media," p. 16) 
intermedial. ${ }^{10}$ However, considered in the light of recent developments, the two poles de facto correspond only partially to positions in the intertextuality debate. In some approaches (in particular those of the 1990s), intermediality is in fact addressed as a fundamental condition along the lines of Bakhtin's concept of dialogism and Julia Kristeva's theory of intertextuality. But other approaches, for the most part more recent ones, base this conception of intermediality on media-theoretical or media-philosophical positions, without referring to the intertextuality discussion. As Sybille Krämer puts it, "[i]ntermediality is an epistemological condition of media-recognition [Medienerkenntnis]." ${ }^{11}$ And according to Gaudreault and Marion, "a good understanding of a medium [...] entails understanding its relationship to other media: it is through intermediality, through a concern with the intermedial, that a medium is understood." In making this point, they proceed from the assumption that "intermediality [is] found in any process of cultural production."12 Jens Schröter refers to similar ideas with his somewhat unfortunately phrased concept of an "ontological" intermediality, and for W. J. T. Mitchell it goes without saying that "all media are mixed media," implying an intermedial quality per se. ${ }^{13}$ Predominantly focusing

10. This applies to publications on intermediality from both the field of literary studies (for an overview, cf. Irina O. Rajewsky, Intermedialität, p. 43-58) and media studies (cf., for example, Yvonne Spielmann, Intermedialität). The different positions of the intertextuality debate cannot be expounded here in detail. At one end of the spectrum there is the expansive, universalist understanding of intertextuality, an understanding primarily associated with French post-structuralism. Following Bakhtin's concept of dialogism, Julia Kristeva has shaped this understanding of intertextuality as a fundamental condition that encompasses all cultural practices. On the other end of the spectrum there is the more narrow conception of intertextuality as a category for the analysis of specific texts, an understanding which conceives intertextuality as a communicative-semiotic concept, in the sense of a text's concrete and apprehensible strategies. On these different understandings, Manfred Pfister, "Konzepte der Intertextualität," in Ulrich Broich and Manfred Pfister (eds.), Intertextualität. Formen, Funktionen, anglistische Fallstudien, Tübingen, Niemeyer, 1985, p. 1-30; Heinrich F. Plett, "Intertextualities," in Heinrich F. Plett (ed.), Intertextuality, Berlin, New York, de Gruyter, 1991, p. 3-29.

11. Sybille Krämer, "Erfüllen Medien eine Konstitutionsleistung? Thesen über die Rolle medientheoretischer Erwägungen beim Philosophieren,” in Stefan Münker, Alexander Roesler, Mike Sandbothe (eds.), Mediemphilosophie. Beiträge zur Klärung eines Begriffs, Frankfurt am Main, Fischer, 2003, p. 82.

12. André Gaudreault, Philippe Marion, "The Cinema as a Model for the Genealogy of Media," p. 15, p. 16.

13. Cf. Jens Schröter, "Intermedialität”; W. J. Thomas Mitchell, Picture Theory: Essays on Visual and Verbal Representation, Chicago, London, University of Chicago Press, 1994, p. 5. 
on current (digital) media, and therefore not quite as radical in their position, Jay David Bolter and Richard Grusin also come to the conclusion that "all mediation is remediation," understanding "remediation" as a particular kind of intermedial relationship. ${ }^{14}$

The third fundamental possibility for distinguishing different approaches to intermediality, one which is closely interwoven with the first two, operates at the level of the analyzed phenomena per se. Designating or not designating a particular phenomenon as intermedial depends on a given approach's disciplinary provenance, its corresponding objectives, and the (explicit or implicit) underlying conception of what constitutes a medium. While a fair amount of overlap occurs between the different disciplinary perspectives on intermedial phenomena, it is still possible to identify certain common tendencies: for instance, approaches coming out of literary, or so-called media-philological studies primarily emphasize the forms and functions of intermedial practices in given media products or medial constellations. By contrast, approaches derived from media studies tend not to focus on already medialized configurations (such as individual films, texts, paintings, etc.), but instead on the very formation of a given medium, on the process of mediation or medialization as such, and on medial transformation processes. ${ }^{15}$ While other, more media-philosophical approaches predominantly aim at questions of media-recognition (Medienerkenntnis) or at understanding the various functions of media. Moreover, each of these types of approaches in turn offers varying definitions of intermediality, depending on the specific, individual phenomena it examines. Such a variety of definitions and emphases in no way reflects a limitation on the part of any single conception of intermediality, but is due to the extremely broad and heterogeneous nature of the subject-matter itself. Some approaches have introduced models that position different objects on a scale of a greater or lesser degree of intermediality, precisely to do justice to the

14. Jay David Bolter, Richard Grusin, Remediation. Understanding New Media, Cambridge, Massachusetts, London, MIT Press, 2000 [1999], p. 55. Henceforth, references to this text will be indicated by the initials "REM," followed by the page numbers, and placed between parenthesis in the body of the text. Cf. also Jay David Bolter, "Transference and Transparency: Digital Technology and the Remediation of Cinema," in this volume, p. 13-26.

15. Cf., for instance, Joachim Paech, "Intermedialität. Mediales Differenzial und transformative Figuration," and Wilhelm Füger, "Wo beginnt Intermedialität? Latente Prämissen und Dimensionen eines klärungsbedürftigen Konzepts," both articles in Jörg Helbig (ed.), Intermedialität. Theorie und Praxis eines interdisziplinären Forschungsgebiets, Berlin, Erich Schmidt, 1998, p. 14-30 and p. 41-57. 
wide range of intermedial phenomena. Then there are those approaches which concentrate instead on one kind of phenomena per se (e.g., film adaptations, ekphrasis, or "musicalization of literature"), and also those approaches, such as my own, which take into account a broader range of phenomena, acknowledging a wider variety of intermedial qualities and thereby introducing more narrowly defined subcategories of intermediality.

\section{A LITERARY CONCEPTION OF INTERMEDIALITY: INTERMEDIALITY IN THE MORE NARROW SENSE OF MEDIAL TRANSPOSITION, MEDIA COMBINATION, AND INTERMEDIAL REFERENCES}

In literary studies as well as in such fields as art history, music, theater, and film studies, there is a repeated focus on an entire range of phenomena qualifying as intermedial. Examples include those phenomena which for a long time have been designated by terms such as transposition d'art, filmic writing, ekphrasis, musicalization of literature, as well as such phenomena as film adaptations of literary works, "novelizations," visual poetry, illuminated manuscripts, Sound Art, opera, comics, multimedia shows, hyperfiction, multimedial computer "texts" or installations, etc. Without a doubt, all of these phenomena have to do in some way with a crossing of borders between media and are in so far characterized by a quality of intermediality in the broad sense. However, it is also immediately apparent that the intermedial quality of a film adaptation, for example, is hardly comparable-or is comparable only in the broadest sense-to the intermediality of so-called filmic writing, and that both of these are quite distinct from, say, book illustrations or Sound Art installations. If the use of intermediality as a category for the description and analysis of particular phenomena is to be productive, we should, therefore, distinguish groups of phenomena, each of which exhibits a distinct intermedial quality.

It is in this way-to return to the three fundamental distinctions underlying different conceptions of intermediality-that my approach to intermedial phenomena follows a synchronic direction; it seeks to distinguish different manifestations of intermediality, and to develop a uniform theory for each of them. However, this approach does not exclude a historical dimension. Instead, it presumes that any typology of intermedial practices must be historically grounded. In fact, the criterion of historicity is relevant in various ways: with regard to the historicity of the particular intermedial configuration itself, with regard to the (technical) development of the media in question, with regard to the historically changing conceptions of art and media on the part of the media's recipients and users, and finally with regard to the functionalization of intermedial strategies 
within a given media product. In this approach, therefore, intermediality is not bound to a uniform, fixed function. It analyses individual instances in terms of their specificity, taking into account historically changing possibilities for the functionalization of intermedial practices.

As can easily be seen, my approach complements the second of the two poles structuring the intermediality debate: the focus is on intermediality as a category for the concrete analysis of texts or other kinds of media products. My emphasis, then, is neither on general media-historical developments or genealogical relations between media, nor on media-recognition (Medienerkenntnis), on what Schröter calls "ontological" intermediality, or on understanding the various functions of media. Nor am I concerned with the processes of medialization as such. Rather, I concentrate on concrete medial configurations and their specific intermedial qualities. These qualities vary from one group of phenomena to another and therefore call for different, narrower conceptions of intermediality. This allows for drawing distinctions between individual subcategories of intermediality, and for developing a uniform theory for each of them.

I should like to propose the following three subcategories:

1. Intermediality in the more narrow sense of medial transposition (as for example film adaptations, novelizations, and so forth): here the intermedial quality has to do with the way in which a media product comes into being, i.e., with the transformation of a given media product (a text, a film, etc.) or of its substratum into another medium. This category is a production-oriented, "genetic" conception of intermediality; the "original" text, film, etc., is the "source" of the newly formed media product, whose formation is based on a media-specific and obligatory intermedial transformation process.

2. Intermediality in the more narrow sense of media combination, which includes phenomena such as opera, film, theater, performances, illuminated manuscripts, computer or Sound Art installations, comics, and so on, or, to use another terminology, so-called multimedia, mixed media, and intermedia. ${ }^{16}$ The intermedial quality

16. The term "intermedia" is indebted to Dick Higgins's pioneer 1966 essay "Intermedia” (in Something Else Newsletter, Vol. 1, No. 1, 1966, reprinted in Dick Higgins, Horizons. The Poetics and Theory of the Intermedia, Carbondale, Edvardsville, Southern Illinois University Press, 1984), in which Higgins expresses his conviction that "much of the best work being produced today seems to fall between media." (p. 18) His understanding of the term has become relevant for attempts to delimit so-called intermedia from mixed media and multimedia. Higgins uses "intermedia" to refer to works "in which the materials of various more established art forms are 'conceptually fused' rather than merely juxtaposed” (Eric Vos, “The Eternal Network. Mail Art, Intermedia Semiotics, 
of this category is determined by the medial constellation constituting a given media product, which is to say the result or the very process of combining at least two conventionally distinct media or medial forms of articulation. These two media or medial forms of articulation are each present in their own materiality and contribute to the constitution and signification of the entire product in their own specific way. Thus, for this category, intermediality is a communicative-semiotic concept, based on the combination of at least two medial forms of articulation. The span of this category runs from a mere contiguity of two or more material manifestations of different media to a "genuine" integration, an integration which in its most pure form would privilege none of its constitutive elements. ${ }^{17}$ The conception of, say, opera or film as separate genres makes explicit that the combination of different medial forms of articulation may lead to the formation of new, independent art or media genres, a formation wherein the genre's plurimedial foundation becomes its specificity. ${ }^{18}$ From a historical perspective then, this second category of intermediality emphasizes dynamic, evolutionary processes, what Aage Hansen-Löve (1983) described as a wearing down (abschleifen) and a newly constituting.

3. Intermediality in the narrow sense of intermedial references, for example references in a literary text to a film through, for instance, the evocation or imitation of certain filmic techniques such as zoom shots, fades, dissolves, and montage editing. Other examples include the so-called musicalization of literature, transposition d'art, ekphrasis, references in film to painting, or in painting to photography, and so forth. Intermedial references are thus to be understood as meaning-constitutional strategies that contribute to the media product's overall signification: the media product uses its own media-specific means, either to refer to a specific, individual work produced

Interarts Studies," in Ulla-Britta Lagerroth, Hans Lund and Erik Hedling (eds.), Interart Poetics. Essays on the Interrelations of the Arts and Media, Amsterdam, Atlanta, Rodopi, 1997 , p. 325); the quality of medial juxtaposition is ascribed (with certain fine distinctions) to so-called mixed media and multimedia (see in more detail also Claus Clüver, "Inter textus / Inter artes / Inter media").

17. Cf. also Werner Wolf, The Musicalization of Fiction, p. 40 et sq.

18. In this context one might ask to what extent, in the case of so-called intermedia -including, for example, visual poetry and corporate logos-, one can in fact speak of a "combination" of different medial forms of articulation, since the constitutive medial forms become quasi inseparable. This extreme outer pole of media combinations concerns phenomena in which individual media or their material manifestations-such as word and image-become inextricably bound to, or even "merged" with, one another, and as such "are simultaneously and oscillatingly present" (Aage A. Hansen-Löve, "Intermedialität und Intertextualität. Probleme der Korrelation von Wort-und Bildkunst-Am Beispiel der russischen Moderne," in Wolf Schmid and Wolf-Dieter Stempel (eds.), Dialog der Texte. Hamburger Kolloquium zur Intertextualität, Wien, Wiener Slawistischer Almanach, 1983, p. 325; my translation). 
in another medium (i.e., what in the German tradition is called Einzelreferenz, "individual reference"), or to refer to a specific medial subsystem (such as a certain film genre)or to another medium qua system (Systemreferenz, "system reference"). The given product thus constitutes itself partly or wholly in relation to the work, system, or subsystem to which it refers. In this third category, as already in the case of media combination, intermediality designates a communicative-semiotic concept, but here it is by definition just one medium-the referencing medium (as opposed to the medium referred to) - that is materially present. Rather than combining different medial forms of articulation, the given media-product thematizes, evokes, or imitates elements or structures of another, conventionally distinct medium through the use of its own media-specific means. ${ }^{19}$

With respect to this tripartite division, it is important to note that a single medial configuration may certainly fulfill the criteria of two or even of all three of the intermedial categories outlined above. As films, for instance, film adaptations can be classified in the category of media combination; as adaptations of literary works, they can be classified in the category of medial transposition; and if they make specific, concrete references to a prior literary text, these strategies can be classified as intermedial references. For of course-and this is de facto almost always the case-the product resulting from a given medial transposition can exhibit, over and above the obligatory medial transformation process itself, references (back) to the original work. Hence, in the case of the film adaptation, the viewer "receives" the original literary text along with seeing the film, and specifically receives the former in its difference from or equivalence to the latter. This reception occurs not (only) on account of any prior knowledge or cultural background the viewer may have, but on account of the film's own specific constitution. It opens up additional layers of meaning which are produced specifically by this referencing or "putting into a relation" of film and text. Rather than being simply based on a pre-existent, original literary work, then, a film adaptation may be constituted in relation to the literary work and thus fall into the category of intermedial references.

The subdivision of intermedial practices into medial transposition, media combination, and intermedial references, is of course in no way exhaustive, doing justice neither to the broad range of phenomena nor to the great variety of objectives that characterize the intermediality debate as a whole. It is particularly associated with analyses of intermediality in the fields of literary studies and

19. My use of the term "imitation" is not intended to connote the traditional notion of mimesis. Rather, it connotes a simulation in the literal sense of the word, not in the sense the word is used in media studies (i.e., to designate mathematical simulation processes). 
interarts studies, where the phenomena covered by all three categories make up the focus of the discussion. As not all three categories can be expounded here in detail, the following remarks will concentrate on the third category, i.e., on intermedial references, which, due to their specific way of relating a given media product to other media and due to their significance for meaning-constitutional processes, are of particular interest.

\section{INTERTEXTUALity, INTERMEDiality AND the “AS If” CHARActer OF INTERMEDIAL REFERENCES}

Intermedial references, inasmuch as they are addressed at all, are generally theorized through concepts of intertextuality. There is indeed a close relation between intermedial references and intertextual or, more broadly conceived, intramedial references, and numerous insights of the intertextuality debate-for instance questions of textual markers and different modes of referencing-can be fruitful for the examination of intermedial phenomena. For this to happen, however, it is important first of all to be clear about how such concepts as text and intertextuality are being used, for whether one uses a narrow concept (as in the case of my approach) or a broad concept (as in the case of Julia Kristeva's vastly expanded, metaphorical notion) will have decisive consequences for the resulting conception of intermedial references. ${ }^{20}$ Secondly-and this should be particularly emphasized - , all comparability notwithstanding, the distinctions between intermedial and intramedial references must not be ignored. These distinctions are due to the fact that intermedial references by definition imply a crossing of media borders, and thus a medial difference (whereas intramedial references by definition remain within a single medium). This medial difference gives rise, or at least can give rise, to the so-called "as if" character of intermedial references, as well as to a specific, illusion-forming quality inherent in them (with the exception of "mere thematizations" of the other medium). ${ }^{21}$

20. A narrow conception of "text" implies that intertextuality is understood in the limited sense of references by a (literary) text either to individual other texts or to literary (sub)systems. Thereby, intertextuality is understood as merely a subcategory of intramedial references. Under the latter category we could also classify references by an individual film to another film or to filmic (sub)systems, references by an individual painting to another painting or to painterly (sub)systems, etc.

21. I use the term "illusion-forming quality" in full awareness of its theoretical and terminological implications, evoking as it does a conception of illusion that has been developed mainly in the context of realist narrative. Yet my use of the concept here falls outside of this context: my emphasis is not on the overall illusion manufactured by the 
This "as if" character and illusion-forming quality can be illustrated through the example of literary references to film: "The literary author writes," as Heinz B. Heller explains, "as if he had the instruments of film at his disposal, which in reality he does not."22 Using the media-specific means available to him, the author of a text cannot, for example, "truly" zoom, edit, dissolve images, or make use of the actual techniques and rules of the filmic system; by necessity he remains within his own verbal, i.e., textual, medium. In this inability to pass beyond a single medium, a medial difference-an "intermedial gap"-is revealed, one which a given text intentionally displays or conceals, but which in any case can only ever be bridged in the figurative mode of the "as if." Intermedial references, then, can be distinguished from intramedial (and thus intertextual) ones by the fact that a given media product cannot use or genuinely reproduce elements or structures of a different medial system through its own media-specific means; it can only evoke or imitate them. Consequently, an intermedial reference can only generate an illusion of another medium's specific practices. And yet it is precisely this illusion that potentially solicits in the recipient of a literary text, say, a sense of filmic, painterly, or musical qualities, or-more generally speaking-a sense of a visual or acoustic presence. Tellingly, it is this sensing by the recipient of another medium's specific qualities that has led to the coining of such metaphor-

work, i.e., on an aesthetic illusion that is obtained at the level of the "reality" presented by, say, a text. Instead, the concept is based on an illusion that aims for an analogy between (in this case) a text's and another medium's respective principles, rules of communication, and strategies. Both these conceptions share the character of a simulation of experience; in the first, however, it is the histoire which is at stake, whereas the second concentrates on the discours (and its various ways of presenting or "staging" a "reality"). What should be emphasized is that intermedial references for their part obviously also have an effect on the overall illusion generated by a given text or other media product; depending on how they are deployed, in fact, they can work to undermine this illusion or promote it. On "mere thematizations," a particular type of intermedial references that is an exception to the following remarks, Werner Wolf, The Musicalization of Fiction; and "Intermediality Revisited. Reflections on Word and Music Relations in the Context of a General Typology of Intermediality," in Suzanne M. Lodato, Suzanne Aspden, and Walter Bernhart (eds.), Word and Music Studies: Essays in Honor of Steven Paul Scher and on Cultural Identity and the Musical Stage, Amsterdam, Atlanta, Rodopi, 2002, p. 13-34; Irina O. Rajewsky, "Intermedialität 'light'?"

22. Heinz B. Heller, "Historizität als Problem der Analyse intermedialer Beziehungen. Die ‘Technifizierung der literarischen Produktion' und 'filmische' Literatur,' in Albrecht Schöne (ed.), Akten des VII. Internationalen Germanistenkongresses. Göttingen (1985), Bd. 10, Tübingen, Niemeyer, 1986, p. 279 (my translation and emphasis). 
IN T ERMEDIALITY, IN T ERTEXTUALITY, AND REMEDIATION

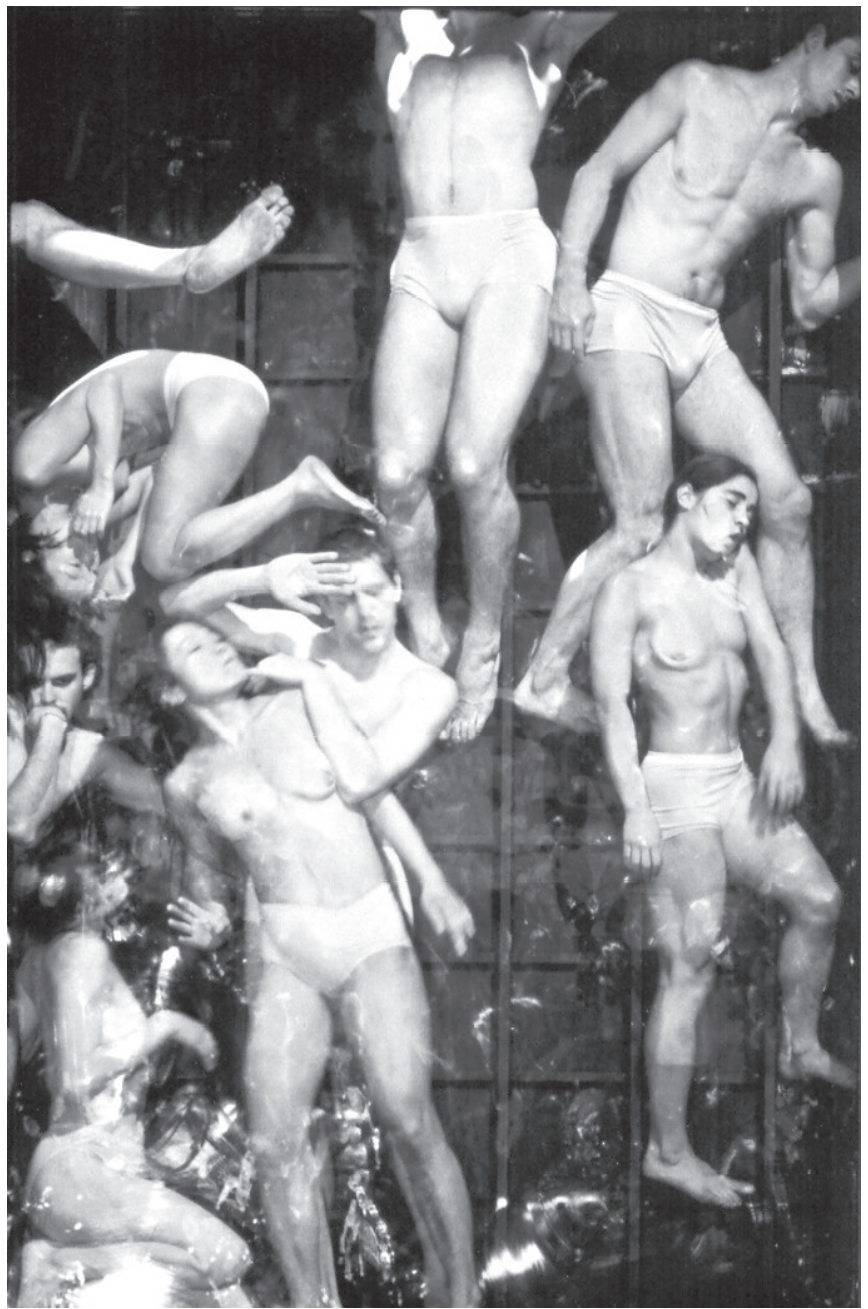

Fig. 1. Körper (Bodies), Schaubühne am Lehniner Platz, Berlin (Co-production with the Théâtre de la Ville, Paris), 20oo. Direction and choreography: Sasha Waltz. Photo (C) Bernd Uhlig (used by permission). 
ical phrases as "filmic writing" or "musicalization of literature," phrases which strongly influenced the literary debate on relations between media before the advent of the concept of intermediality.

Just as a literary text can evoke or imitate specific elements or structures of film, music, theatre, etc., so films, theatrical performances, or other media products can constitute themselves in various complex ways in relation to another medium. In a particularly impressive way such a "putting into relation" of one medium and another has, to give just one example, been realized in the dance theatre production Körper (Bodies) by Sasha Waltz (Berlin, 2000; fig. 1-2). At a certain point of the piece a huge picture-frame-like construction is erected on the stage, equipped with a transparent front and an opaque panel in the back. Stuck between the transparent front-pane and the back-panel and supporting themselves in the air by pressing their limbs against the two "walls," the dancers move very slowly, head up and head down, in every possible direction; seemingly weightless and as if freed from the necessity to touch ground. With several other factors contributing to its overall effect (a particular lighting, the dancers' costumes recalling loincloths, bodies seemingly cut off at the borders of the frame, etc.), this sequence as a whole inevitably reminds the viewer of a painting, maybe even more specifically of a mannerist one.

Here, in fact, the means and instruments of dance theatre (bodies, costumes, movements, lighting, stage props, etc.) are employed and fashioned in a way that corresponds to, and resembles, elements, structures and representational practices of painting, thus creating an illusion of painterly qualities. (Put in cognitivist terms, they cue the spectator to apply painting-bound schemata). The evocation of the medium of painting is not achieved simply by means of subjective associations that may (or may not) be elicited in the viewer's mind. Rather, the placement onstage of an oversized frame-a device that is iconically related to a picture frame, and that effectively "frames" the action taking place onstage-explicitly designates painting as the medial system being referred to, and thus marks the overall mise-en-scène as an intermedial reference to painting. Hence, the sequence as a whole constitutes itself (and is "received" by the viewer) in relation to painting, imitating, but at the same time-as is typical of intermedial references of this kind-also expanding the representational modes of the medium being referred to (for instance, Körper supplements the stasis of painting with the movement of the dancers): it is as if the viewer sees a painting put into motion, turned to life - a tableau vivant in the truest sense of the term.

The oversized frame in Körper is not only of interest in itself (and in its function as a marker), but also because its use onstage makes particularly evident 
IN T E RME D I A L I TY, IN T ERTEXTUALITY, AND REMEDIATION

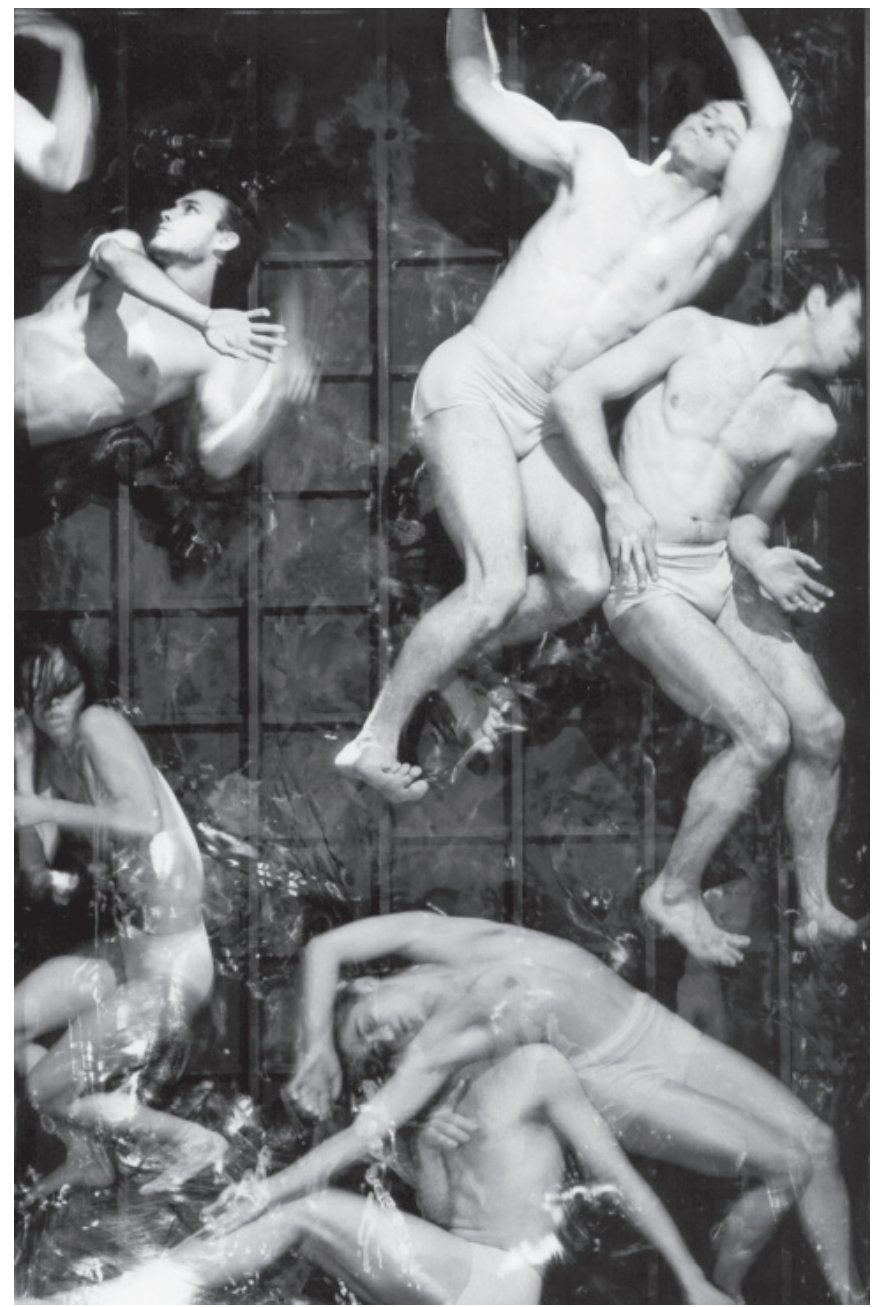

Fig. 2. Körper (Bodies), Schaubühne am Lehniner Platz, Berlin (Co-production with the Théâtre de la Ville, Paris), 200o. Direction and choreography: Sasha Waltz. Photo (C) Bernd Uhlig (used by permission). 
how the means and devices of dance theatre are here being applied in a way that corresponds to the medium referred to. Within the borders of the "image" that is created by the frame, the viewer can see the moving limbs of the dancers. The dancers' bodies are placed partly inside the frame and partly outside of it, but only those parts that are within the frame are visible to the viewer (Fig. 1-2), which do not show the actual frame, but which nevertheless convey the overall effect. In this way, the mise-en-scène does not simply stress the framed-ness of the "image." More to the point, it explicitly references a defining characteristic of painting as such: painting is by definition constrained to present an image that is clearly delimited and finite. Painting can thus only ever create the illusion of a whole that would continue on outside the given frame; consequently, such a whole only ever exists virtually. Bodies and objects cut off at the borders of a given painting promote this illusion of a whole that would lie beyond the frame. In the case of Körper, of course, the whole, i.e., the full bodies of the individual dancers and the entirety of the stage, is in fact tangibly present beyond the borderlines created by the frame. However, by seeming to cut off the dancers' bodies right at those borders, the mise-en-scène creates the illusion of an image that is delimited and finite, and of a corresponding whole that-just as in painting-only exists virtually. It thus produces an effect that corresponds to and that resembles painting, thereby reinforcing the impression of painterly qualities that is evoked by the dance sequence as a whole.

Given the above, the specificities of intermedial references as opposed to both intramedial references and other intermedial phenomena become apparent. First, I should like to emphasize again that in intermedial references, as I understand them, only one conventionally distinct (either monomedially or, as in the case of dance theatre, plurimedially constituted) medium is present in its own specific materiality and mediality. In fact, their definitive intermedial aspect does not have to do with the material manifestations of two or more conventionally distinct media within a single given medial configuration, as is the case in media combinations. (And this is why intermedial references tend to be marginalized by all those approaches that restrict the quality of a "genuine" intermediality to configurations materially constituted by more than one medium). Instead, in intermedial references the definitive intermedial aspect has to do with the reference itself which a given media product (such as a text, film, etc.) makes to an individual product, system, or subsystem of a different medium, and to its medial specificities. Hence, the media product (and its overall signification) constitutes itself in relation to the media product or system to which it refers. This referencing-and this is the second point to be made-is of an intermedial (as opposed 
to an intramedial) nature, and it is on account of the presence or absence of a border-crossing quality, i.e., of a medial difference, that fundamental distinctions between intermedial and intramedial references can be made. Depending on their intermedial or intramedial quality, different possible forms and, maybe even more significantly, different possible functions come into play for the references in question. ${ }^{23}$ This, in turn, has far-reaching consequences for the analysis of any given media product, and it is here that the heuristic potential of drawing a conceptual (and terminological) distinction between intramedial and intermedial references becomes apparent, justifying the necessity of developing a separate, unified theory for each kind of reference.

At the same time, however, it also becomes apparent why I initially insisted on clarifying the kinds of phenomena on which the different approaches to intermediality respectively concentrate, and on delimiting the specific objectives as well as the heuristic and practical value (and limitations) of those approaches. Here, the concept of remediation may serve as a test case. "Remediation," as conceived by Bolter and Grusin, denotes a particular kind of intermedial relationships in which, through processes of medial refashioning, "both newer and older [media] forms are involved in a struggle for culture recognition." 24 Focusing on digital media, Bolter and Grusin argue that "all current media remediate," (REM, p. 55) and thus pay homage to as well as rival, earlier media by "appropriating and refashioning the representational practices of these older forms." 25 Similarly, also earlier media, such as painting, (literary) texts, photography, film, etc., have frequently remediated (and continue to remediate) both the respective newer media as well as one another. Hence, according to Bolter and Grusin, remediation can be termed a "defining characteristic of the new digital media" (REM, p. 45) and, more generally speaking, a fundamental, if not inevitable, trait of (current) medial practices.

In order to verify these conclusions, Bolter and Grusin, for one, give an overview of how newly emerging media have all along remediated earlier media's

23. The various possible forms of intermedial references, and their nuanced differences from intramedial references, cannot be expounded here in detail. Cf. Irina O. Rajewsky, Intermedialität, for details.

24. Jay David Bolter, "Transference and Transparency," p. 14.

25. Jay David Bolter, "Transference and Transparency", p. 14. This definition of remediation seems more adequate than the earlier definition, where remediation was defined as "representation of one medium in another" (REM, p. 45). For instance, a film adopting computer technology can hardly be said to represent digital media; it much rather makes use of digital technology. 
techniques and practices; how, for instance, Gutenberg and the first generation of printers remediated letterforms and layout from the manuscript, how film has remediated both photography and the practices of stage plays, how in computer graphics paint programs have remediated techniques and names from manual painting or graphic design practices, or how World Wide Web designers have remediated graphic design as it was practiced for printed newspapers and magazines (REM, p. 68 et sq.). For another, they refer to a wide range of singular occurrences of remediation practices from the realm both of new digital media as well as earlier media forms, e.g., remediation in certain computer and video games, in specific films adopting or thematizing digital technology, in photorealistic paintings and photorealistic computer graphics, in ekphrastic texts, and so forth.

The occurrences cited by Bolter and Grusin can indeed all be taken as examples of a widespread and increasing, or even of an inevitable, fundamental correlation between newer and earlier media. And they are all apt to convincingly substantiate one of the main theses the authors put forward, namely, that " $[n]$ o medium today, and certainly no single media event, seems to do its cultural work in isolation from other media, any more than it works in isolation from other social and economic forces." (REM, p. 15)

Yet, seen from a different angle, there are significant differences between the individual examples cited by Bolter and Grusin. To mention only three aspects in this context: for one, there are fundamental differences between the two groups of examples given by Bolter and Grusin. On the one hand, there are those remediation practices that from a genealogical point of view can generally be attributed to given (newly emerging) media; on the other, there are concrete instances of remediation in single media products. An example for the first category would be film's general remediation of photography and theatre, while an example for the second would be a particular film that (over and above a general "indebtedness" to photography and theatre) makes reference, and thus constitutes itself in relation, to photography or theatre. Only in the latter case a meaning-constitutional strategy is at issue, relevant for the overall signification of the given film.

Secondly, concentrating on concrete instances of remediation strategies and returning to the above remarks on the tripartite division of intermedial subcategories, there are noteworthy differences between, say, a film making use of digital technology and a painting, which, using its own specific means, imitates a photographic quality (as in photorealistic painting). In the latter case-an intermedial reference with a strongly meta-medial function and interesting implications for the artifact's (doubly figurative) referential function-the difference between the media involved comes into play in a manner significantly different from the first 
case, which was an example of media combination (even though computer technology could by now be seen as a standard feature in film and thus as part of the per se plurimedial quality of film). Accordingly, to return to the example from Sasha Waltz's Körper, the illusion of painterly qualities in the sequence described above is to be distinguished from the per se plurimedial character of dance theater productions: the former is achieved through intermedial referencing and not, as in the latter case, through a combination of different medial forms of articulation that are each present in their own materiality. This, in turn, has important implications both for theorizing the phenomena in question as well as for the concrete analysis of a given media product and its overall signification (here, of course, also varying possible functionalizations of intermedial strategies come into play).

Finally, a uniform handling of remediation practices tends to obscure a specificity of digital media as opposed to any non-digital medium. In fact, computer technology, with its increasing capability to (more or less) "perfectly" simulate earlier media forms, does not quite fit into a division of different intermedial subcategories as introduced above, and even more generally challenges any definition of intermediality that is based on medial differences (at least if "intermediality" is understood as a critical category for the concrete analysis of individual media products). This can tentatively be shown through the example of computer generated images, though without being able to dwell on the manifold implications the following remarks may lead to.

As has been pointed out, among others, by William J. Mitchell, with digital media it has become possible to create computer generated photos-following Bolter and Grusin a remediation of photography-that viewers cannot distinguish from images taken with an optical camera. ${ }^{26}$ Digital media, therefore, are (more and more convincingly) capable of erasing any perceptible medial difference in their simulation processes. For this reason, the category of intermediality, as outlined above, does not quite seem to work for (these kinds of) computer generated photos, since the point of intermedial practices is precisely a perceptible medial difference between two or more individual media. Once a medial difference is no longer a given, i.e., is no longer discern-

26. Cf. William J. Mitchell, The Reconfigured Eye: Visual Truth in the PostPhotographic Era, Cambridge, Massachusetts, MIT Press, 1994 [1992], p. 161. It should be emphasized that computer technology may (increasingly) be able to simulate almost perfectly the elements and structures of specific media forms, such as photography, yet necessarily it lacks the specific materiality of the simulated medium. Cf. in more detail Jens Schröter, "Intermedialität, Medienspezifik und die universelle Maschine," www.theorie-der-medien.de, 2002. 
ible, any discussion about intermedial practices in given medial configurations becomes pointless (at least if we do not adopt an exclusively genealogical point of view). ${ }^{27}$ Therefore, in cases like computer generated photography, digital media seem to be forced to include in their (necessary) simulation processes not only the simulation of the other medium's specific qualities, forms and structures, but also the simulation of a perceptible medial difference, in order to create a discernible effect of intermediality. Thus, one could conclude, digital technology opens up a field of a simulated-of a "virtual"-intermediality (virtualizing and dematerializing the "reality" of intermedial cultural practices), a field that hitherto has been occupied uniquely by digital media. ${ }^{28}$

It thus follows that concepts like media combination and intermedial references, and, ultimately, any conception of intermediality as a category for the concrete analysis of given medial configurations, come up against their own internal limitations as soon as digital media and their particular-mathematical-simulation processes are in question (even if these limits can be overcome by strategies of a "virtual" intermediality). If, however, we take those approaches to intermediality into account, that adopt a genealogical point of view or concentrate on general questions of media-recognition, or of how media are or can be understood, a different understanding of intermedial relationships comes to the fore: here, the main focus is not on the specific ways in which intermedial practices are realized in, and take part in the overall signification of a given media product, but, more generally, on the fundamental interrelatedness of earlier and newer media. Consequently, departing from this kind of research perspective, the particular differences between digital and non-digital media are only of relative importance: even if in certain computer-generated photos a medial difference should no longer be discernable, and if, therefore, it becomes problematic to attribute an intermedial quality to the image itself, the same image, from a

27. Cf. on this also Joachim Paech, "Intermedialität des Films," in Jürgen Felix (ed.), Moderne Film Theorie, Mainz, Bender, 2002, p. 300; Yvonne Spielmann, "Intermedialität und Hybridisierung," in Roger Lüdeke, Erika Greber (eds.), Intermedium Literatur, p. 78-102.

28. On the fundamental differences between digital and non-digital media, see in more detail Jens Schröter ("Intermedialität, Medienspezifik und die universelle Maschine") who speaks of a "virtual" intermediality, and Yvonne Spielmann who, in this context, introduces the idea of a "remediation of intermediality" ("Intermedialität und Hybridisierung," p. 91). Taking this one step further, one could conclude that digital media not only remediate earlier media and their respective representational practices, but specific intermedial relationships between these earlier media as well. In short: digital media remediate remediation practices of earlier media, they remediate remediation. 
genealogical point of view, still demonstrates its (intermedial) relation to another medium, in this case optical photography.

It is in this sense that Bolter and Grusin define "remediation" as a particular kind of intermedial relationship; and it is in this sense that the concept of remediation can indeed be said to be suitable to cover the entire range of heterogeneous examples cited by Bolter and Grusin in this regard. Digital media, in fact, remediate pre-existent media forms via simulation, appropriating and (to a greater or lesser extent) refashioning their specific qualities, structures, techniques, or representational practices (e.g., linear perspective in computer graphics), including, one could add, even their respective remediation strategies. But of course also, numerous ways in which non-digital media have reacted (and continue to react) to both digital and earlier media can be subsumed under the heading of "remediation," since all of them indicate that medial practices do not occur in isolation from, but in a "constant dialectic" (REM, p. 50) with other media.

Hence, "remediation" can indeed be classified as a particular type of intermedial relationship, and consequently as a subcategory of intermediality in the broad sense. And yet, it is hardly reconcilable with conceptions of intermedial subcategories like medial transposition, media combination, or intermedial references. Just as the concept of intermediality on a more general level, "remediation" allows to subsume under one heading the most heterogeneous instances of a widespread cultural phenomenon. In this way, it allows to highlight a fundamental, transhistorically and transmedially relevant, and, according to Bolter and Grusin, in principle invariable, "double logic" of remediation processes, located within "our culture's contradictory imperatives for immediacy and hypermediacy" (REM, p. 5). Yet, on the other hand, and this is where the other research perspective comes into play, the concept necessarily implies a tendency to level out significant differences both between the individual phenomena in question and between different media with their respective materiality; differences that come to the fore as soon as detailed analyses of specific medial configurations, their respective meaning-constitutional strategies, and their overall signification are at stake.

What is at issue here, this should again be emphasized, is not a potential shortcoming of any individual approach to intermediality. Quite on the contrary-and with this my argument has come full circle-, it is the importance of specifying each particular understanding of intermediality (in a narrower sense), and of clarifying in respect to which objects and to which epistemic objectives it gains heuristic and practical value. 